\title{
Dorota Brzozowska \\ Polski dowcip etniczny. Stereotyp a tożsamość \\ Wydawnictwo Uniwersytetu Opolskiego, Opole 2008, ss. 240
}

Rozprawa Doroty Brzozowskiej sytuuje się w obszarze jej badań nad dowcipem etnicznym, stereotypami i tożsamością. Stanowi więc swoisty zwornik całej dotychczasowej twórczości naukowej opolskiej lingwistki. Jej cel formułuje autorka następująco:

"Celem opracowania jest przedstawienie wielowymiarowości zjawiska tożsamości narodowej $w$ kontekście polskiego dyskursu ludycznego osadzonego we współczesnej przestrzeni komunikacyjnej. Jej ramy czasowe wyznacza transformacja ustrojowa zachodząca od roku 1989, wpływająca na zmiany w sposobie życia i mentalności Polaków" (s. 10).

U podstaw rozprawy leży założenie, , ,[...] że miejsca wspólne dyskursów tożsamościowego i ludycznego znajdują doskonałe odzwierciedlenie $\mathrm{w}$ dowcipach, najbardziej reprezentatywnym gatunku tego dyskursu, w którym jak w soczewce uwidaczniają się bolączki społeczne. Ten obraz przerysowany, ale jednocześnie wyrazisty chcę tu pokazać, by przez uporządkowanie najważniejszych powtarzających się wątków uwypuklić centralne miejsca, wokół których skupia się społeczny śmiech oraz stojąca za nim troska o kształt społeczeństwa i wyznawanych przez niego [sic! - B. W.] wartości" (s. 11).

Interdyscyplinarny (tym terminem posługuje się autorka - ja bym był skłonny uznać za właściwszy w tym kontekście termin transdycyplinarny) charakter tytułowego zagadnienia powoduje, że Brzozowska ukazuje polski dowcip etniczny $z$ trzech perspektyw: „,...] językoznawczej (jako gatunek tekstu włączony w semantyczną teorię humoru), socjologicznej oraz historycznej. Połączenie tych trzech optyk pozwala na interdyscyplinarną analizę dowcipów, w której centrum znajdują się pytania o związki 
między stereotypami a obecnymi w dowcipach skryptami" (s. 11) (przez skrypt autorka rozumie 'porcję informacji semantycznej, otaczającą lub wywołaną przez dane słowo': „Skrypt jest kognitywną strukturą przyswojoną przez użytkownika języka i reprezentuje jego wiedzę o pewnej części świata. Oprócz skryptów wiedzy lingwistycznej [winno być: językowej - B. W.], specjalistycznej i potocznej każdy dysponuje skryptami indywidualnymi, dzieli je $\mathrm{z}$ określonymi grupami społecznymi (rodzina, sąsiedzi, koledzy), ale nie z całym społeczeństwem [...]" (s. 28)).

Źródłowo-materiałową podstawę rozprawy stanowi korpus dowcipów wyekscerpowanych $\mathrm{z}$ wydawnictw zwartych i broszurowych, z prasy i stron internetowych oraz krążących w obiegu ustnym. "Centralną pozycję zajmują dowcipy najnowsze, reprezentowane $w$ pracy najliczniej. Im większa od nich odległość czasowa, tym częściej zatrzymuję się tylko przy tekstach, które były niezbędne do zilustrowania jakiegoś bardziej powszechnego i charakterystycznego zjawiska $z$ przeszłości, mającego skutki w teraźniejszości" (s. 11). Za uzasadnione należy uznać postępowanie autorki, kierującej się $w$ doborze badanych tekstów dyrektywą stanowiącą, że „[...] optymalne rozmiary materiału określa nie tyle ustalona arbitralnie liczba, co "nasycenie”, osiągnięcie takiego stanu, w którym nowe materiały nie przynoszą już żadnych nowych, znaczących informacji [...]. Podstawowy korpus uzupełniałam dodatkowymi przykładami tam, gdzie mogły one posłużyć lepszej ilustracji omawianego zjawiska, mniejszą uwagę poświęcając tekstom, które niosły informacje redundantne" (s. 12-13).

Ponieważ stereotypy nigdy nie dotyczą etnosów, które nie mają dla nas znaczenia, lecz zawsze są wizerunkami "znaczących innych" „[...] tych grup, zbiorowości czy narodów, które są dla nas ważne, z którymi wiążą nas istotne relacje i w stosunku do których określamy własną tożsamość [...]" (s. 23), centralne miejsce w rozprawie przypada „[...] klasycznej dla dowcipu polskiego triadzie - „Polak, Rusek, Niemiec" [...]. W oddzielnym rozdziale zajmuję się dowcipami o Żydach, których wpływ na zasoby rodzimej twórczości humorystycznej jest nie do pominięcia. W portrecie istotnych dla kultury współczesnej grup nie może zabraknąć wizerunku Amerykanów, których znaczenie rośnie wraz z postępującą globalizacją [...]" (s. 12).

Przyjętą w pracy metodologię badaczka najogólniej określa za pomocą formuły: „[...] porównywanie i analiza tekstów, polegająca na schodzeniu w głąb pod ich powierzchnię, by wydobyć ukryte sądy, przekonania 
i założenia, których teksty te są zewnętrzną manifestacją" (s. 39). Jest to metodologia kognitywistyczna (autorka wprost się odwołuje do profilowania $w$ ujęciu Jerzego Bartmińskiego (jako 'sposobu ujmowania przedmiotu z różnych punktów widzenia, kształtowania pojęcia $\mathrm{w}$ zależności od odnoszenia się do niego określonego podmiotu'), objaśniając i uzasadniając operacyjną przydatność pojęć profilu ('wariantu znaczenia relatywizowanego podmiotowo, wynikającego z subiektywnej konceptualizacji tego samego przedmiotu'), punktu widzenia ('czynnika podmiotowo-kulturowego, decydującego o sposobie mówienia o przedmiocie'), domeny kognitywnej, fasety itd. (s. 40)). Zastosowaną metodologię trzeba uznać za uzasadnioną $\mathrm{i}$ adekwatną $\mathrm{z}$ jednej strony do zgromadzonego materiału przykładowego, a $\mathrm{z}$ drugiej do założonych celów pracy.

O wartości rozprawy Doroty Brzozowskiej stanowią - moim zdaniem - przede wszystkim następujące aspekty i elementy:

1) Bogactwo materiału przykładowego. Zgromadzony korpus dowcipów liczy ponad dwa tysiące przykładów (40\% stanowią w nim teksty internetowe, $25 \%$ - teksty $\mathrm{z}$ wydawnictw zwartych, $25 \%$ - z wydawnictw broszurowych, $5 \%$ - teksty drukowane w prasie i $5 \%$ - teksty $z$ obiegu ustnego, zanotowane przez autorkę). Liczba źródeł drukowanych obejmuje 34 pozycje, a źródeł internetowych - 62 pozycje.

2) Imponujące zaplecze erudycyjne rozprawy. Spis literatury przedmiotu (s. 219-231) obejmuje 305 pozycji (w językach: polskim, angielskim i niemieckim), z czego znacznie więcej niż połowa (173 pozycje) to książki, nierzadko bardzo obszerne. Warto przy tym podkreślić, że nie chodzi tu bynajmniej o erudycyjny popis: znajomość rozległej literatury przedmiotu (z obszaru wielu dyscyplin naukowych) ma charakter „sfunkcjonalizowany", jej wyniki, umiejętnie wyzyskane przez autorkę, są obecne i widoczne w tekście jej pracy, która dzięki temu zyskuje na głębi i gruntowności.

3) Informacyjny i porządkujący walor rozdziału wstępnego Podstawy teoretyczne $i$ metodologiczne badań (s. 15-40). Autorka - wyczerpująco (jak na użytek rozprawy), choć bardzo zwięźle - omawia w nim, w trybie wieloaspektowym, uwzględniając perspektywę badawczą różnych dyscyplin naukowych (językoznawstwa, literaturoznawstwa, kulturoznawstwa, filozofii, psychologii, socjologii, politologii, etnologii, antropologii itp.), kluczowe dla jej wywodu pojęcia tożsamości, stereotypu, dyskursu, dyskursu ludycznego (rozumianego jako jeden z podtypów dyskursu: 'typ wydarzeń komunikacyjnych, w których przekazywaną ideą jest skłon- 
ność do zabawy (od łac. ludus 'gra, zabawa'), a celem interakcji tworzenie „wspólnoty śmiechu"'), dowcipu („Za dowcip prototypowy uznaję krótki tekst o strukturze narracyjno-dialogowej, zakończony zaskakującą puentą" (s. 28)) i dowcipu etnicznego. Równie pożyteczny jest bardzo zwięzły przegląd badań nad stereotypami i humorem. W sumie nie ulega dla mnie wątpliwości, że wstępny rozdział rozprawy przedstawia samoistną wartość naukową i dydaktyczną (oczywiście na poziomie specjalistycznych studiów magisterskich czy doktoranckich).

4) Gruntowność, wielostronność i wnikliwość analizy i interpretacji. W odniesieniu do każdej uwzględnionej grupy etnicznej autorka prezentuje ,[...] charakterystykę odpowiedniego etnonimu, historię stereotypu uwidaczniającą się w poszczególnych grupach tekstów na tle historii relacji między Polakami a omawianą grupą etniczną oraz obraz danej narodowości w relacji do dowcipów współczesnych" (s. 13).

5) Wreszcie - jako skutek wszystkich wyliczonych wyżej walorów interesujące i ważne wyniki naukowe. Niepodobna tu wymienić wszystkich, zwłaszcza licznych szczegółowych. Ograniczę się do przykładowego wskazania kilku spośród (moim zdaniem) najciekawszych i najważniejszych:

a) Wyróżnienie wśród funkcjonujących w Polsce stereotypów etnicznych trzech grup: stereotypów starych, „silnie zleksykalizowanych” (jak Cygan, Kozak czy Tatar), stereotypów zapożyczonych z obiegu międzynarodowego (jak Szkot czy Murzyn) i stereotypów żywych, „[...] odnoszących się do narodowości, z którymi Polacy utrzymują kontakt i wobec których określają swą tożsamość. Są to przede wszystkim: Niemiec i Rosjanin, a w dalszej kolejności Żyd i Amerykanin [...]" (s. 211).

b) Przekonujące ukazanie przemian $w$ polskim dyskursie ludycznym (,W okresie przedwojennym najpopularniejszymi bohaterami dowcipów etnicznych byli Żydzi jako ważni współuczestnicy życia społecznego. W czasie II wojny światowej ich miejsce zajęli alianci i Niemcy, a do upadku komunizmu - głównie Rosjanie. Przedstawiciele dwóch ostatnich narodowości, jako najbliżsi odwieczni sąsiedzi, ustanowili kanon polskich dowcipów etnicznych z ich centralną, tradycyjną serią tekstów o „Polaku, Rusku i Niemcu”. W okresie "zimnej wojny" Rosjanom towarzyszyli jako bohaterowie pozytywni Amerykanie. W dowcipach najnowszych to oni zaczęli zajmować pozycję dominującą" (s. 212)).

c) Wykazanie współczesnej globalizacji dyskursu ludycznego („Latwiejsze i szybsze przemieszczanie się dowcipów sprawia, że teksty po- 
wstające lokalnie w bardzo krótkim czasie stają się rozpoznawalne globalnie" (s. 212)).

d) Zasadna prognoza dynamicznego wzrostu popularności dowcipów etnicznych (na skutek nasilenia ruchów migracyjnych w zjednoczonej Europie, rosnącej wieloetniczności współczesnych społeczeństw, spadku popularności dowcipów politycznych i rozpowszechniania się poprawności politycznej (co powoduje zepchnięcie problematyki etnicznej do sfery dyskursu ludycznego)).

Jedynym bezdyskusyjnym mankamentem rozprawy są drobne błędy szczegółowe (np. Buw zdorow, a w kińci pomer to oczywiście po ukraińsku, a nie po rosyjsku (s. 99), współczesny język Ormian to ormiański, a nie armeński (s. 101) itd. (najwięcej tego typu błędów polega na nieuprawnionych uproszczeniach w płaszczyźnie historycznej)), które w tym samym stopniu co autorkę (a właściwie nawet większym) obciążają recenzentów wydawniczych.

W świetle swojej rozprawy Dorota Brzozowska prezentuje się jako badaczka utalentowana, pracowita, samodzielna i doświadczona. Jej warsztat naukowy odznacza się dwiema szczególnie cennymi i pożądanymi cechami. Są to:

1) Solidne podstawy materiałowe formułowanych tez i wniosków.

2) Postawa badawcza, cechującą się sumiennością i skrupulatnością na każdym etapie postępowania badawczego, umiejętnością łączenia gruntownej, wielostronnej i szczegółowej analizy z dobrze uzasadnioną, podbudowaną obfitym materiałem syntezą, a także chwalebną ostrożnością w wyciąganiu wniosków i formułowaniu tez.

Dzięki takiemu warsztatowi badawczemu osiągnęła Dorota Brzozowska w swojej książce wiele ważnych i wartościowych wyników naukowych (niektóre $z$ nich wskazałem $w$ recenzji), które wejdą do trwałego dorobku językoznawstwa polskiego.

Bogdan Walczak

Uniwersytet Adama Mickiewicza w Poznaniu 